Article

\title{
Exploring Spatiotemporal Variation of Carbon Storage Driven by Land Use Policy in the Yangtze River Delta Region
}

\author{
Wenbo Cai ${ }^{1,2,3}$ and Wanting Peng $1, *$ (D) \\ 1 School of Design \& China Institute for Urban Governance, Shanghai Jiao Tong University, 800 Dongchuan Rd., \\ Minhang District, Shanghai 200240, China; wbcai@rcees.ac.cn \\ 2 State Key Laboratory of Urban and Regional Ecology, Research Center for Eco-Environment Sciences, Chinese \\ Academy of Sciences, Shuangqing Rd. 18, Beijing 100085, China \\ 3 School of Ecological and Environmental Sciences, East China Normal University, 500 Dongchuan Road, \\ Shanghai 200241, China \\ * Correspondence: pw2020@sjtu.edu.cn
}

Citation: Cai, W.; Peng, W. Exploring Spatiotemporal Variation of Carbon Storage Driven by Land Use Policy in the Yangtze River Delta Region. Land 2021, 10, 1120. https://doi.org/ 10.3390/land 10111120

Academic Editor: Nir Krakauer

Received: 16 September 2021

Accepted: 19 October 2021

Published: 22 October 2021

Publisher's Note: MDPI stays neutral with regard to jurisdictional claims in published maps and institutional affiliations.

Copyright: (c) 2021 by the authors. Licensee MDPI, Basel, Switzerland. This article is an open access article distributed under the terms and conditions of the Creative Commons Attribution (CC BY) license (https:// creativecommons.org/licenses/by/ $4.0 /)$.

\begin{abstract}
Land use/land cover (LULC) change driven by land use policy always leads to dramatic change in carbon storage and sequestration, especially in a rapidly urbanizing region. However, few studies explored the influences of land use polices on carbon storage and sequestration in a rapidly urbanizing region. Through Integrated Valuation of Ecosystem Services and Tradeoffs (InVEST) model, the spatial-temporal pattern of carbon storage altered by LULC transformation and its linkage with land use policies were analyzed in five periods (1990-1995, 1995-2000, 2000-2005, 2000-2010, 2010-2015) in the Yangtze River Delta (YRD) Region. The results indicated that: (1) the carbon storage in the YRD was substantially altered by continuous LULC transformation, totally decreased by $1.49 \times 10^{7} \mathrm{Mg}$ during 1990-2015. (2) The total amount of carbon storage increased from $2.91 \times 10^{9}$ $\mathrm{Mg}$ in 1990 to $2.95 \times 10^{9} \mathrm{Mg}$ in 1995, and then decreased to $2.90 \times 10^{9} \mathrm{Mg}$ in 1995-2015. Thus, the total economic value of carbon storage increased approximately from 467.42 million dollars in 1990 to 472.99 million dollars in 1995, and then decreased to 465.01 million dollars in 2015. (3) The carbon storage and sequestration were influenced by LULC transformation driven by land use policies in five periods: large areas of grassland converted to woodland in 1990-1995 led by Forest Law, then clustered areas of cropland converted to built-up land in 1995-2015 around large cities of YRD Region led by Land Management Law and Development Plans, and finally, the conversion of cropland to built-up land was decreased and scattered in the entire region influenced by land use polices led by early stage of ecocivilization construction. The study can facilitate to develop regional land use policy for carbon storage conservation and carbon neutrality in a rapidly urbanizing region.
\end{abstract}

Keywords: carbon storage; land use policy; Yangtze River Delta Region; carbon neutrality; urban governance

\section{Introduction}

The world is experiencing significant urban expansion, which is likely to continue in the future [1,2], that had caused global land landscape alteration resulting from land use/land cover (LULC) change. Rapidly urbanizing regions with deforestation largely reduce the provision of ecosystem service, especially service related to carbon that LULC change is one of the most important source of $\mathrm{CO}_{2}$ emissions [1,3,4]. Regional carbon storage was greatly affected due to the increase of built-up land and the loss of natural vegetation, which seriously threatens the provision of regional ecosystem services and sustainability. Timely and effective assessment of regional carbon storage impacted by urban expansion is essential to maintain carbon storages service while enhancing other ecosystem services [5-7], and thus to improve regional sustainable development through informing regional land management decision-making [1,3,4,8,9].

Regional changes of LULC were a process across a broad range of spatiotemporal scales, caused by natural causes and human activities, which directly affect soil carbon 
and carbon cycle [10-12]. With intensive land use and human activities, environmental policies have become mainly driver and changed LULC constantly. The irrational use of land led to serious land degradation, reducing the provision of carbon storage of all ecosystems lower than the potential carbon storage for a long time [13]. For example, the expansion of built-up land damaged ecosystems such as forest, grassland, that decrease the storage of atmospheric carbon dioxide taking up by trees, grasses, and other plants through photosynthesis [13], thereby reducing the value of ecosystem carbon sequestration services. Previous studies on the impact of LULC change on ecosystem carbon storage have provided important insights and directions for land and environmental policy makers $[3,4,8,9,14-16]$. For instances, Nelson et al. applied InVEST to assess the impact of global urban land change on carbon storage [5]. Leh et al. analyzed the impact of land use and land cover change on carbon storage during 2000-2009 by using InVEST model [17]. Polasky et al. assessed the impact of actual land use change and a series of alternative land use change scenarios on carbon storage in Minnesota from 1992 to 2001, and how to improve regional carbon storage through land management policies was further discussed [18]. Previous studies studied the impact of LULC changes on carbon storage and sequestration. However, few studies explored the influences of land use polices influences on carbon storage and sequestration in a rapidly urbanizing region [15].

China is one of the developing countries with rapid urbanization [19]. Over the past 40 years, China has experienced rapid urbanization and a substantial growth in population as the consequence of economic and political reforms in 1978 [20]. In 2020, China put forth an ambitious goal of carbon peaking by 2035 and carbon neutrality by 2060, which require carbon management-driven land use policies. The Yangtze River Delta (YRD) region is one of the most rapidly urbanized regions in China and experienced a remarkable period of population growth (at an annual growth rate of 3.0\%), and urbanization (at an annual growth rate of 9.2\%) [2]. Rapid urbanization has dramatically changed LULC patterns and ecosystems in the YRD region, causing decline of ecosystem services, e.g., carbon storage [1]. Facing the threats, China put forward New Revised Overall Land Use Planning (2006-2020) calls for scientific demarcation of 'Prime farmland' and comprehensive enhancement of 'Prime farmland' protection [21-23]. After the introduction of national strategy of 'Ecocivilization' in 2012, environmental planning policies e.g., Ecological Redline Policy [24], Prime Farmland Policy [21-23], and preliminary regional environmental cooperation were carried on in the YRD region. The 'Development Plan of Yangtze River Delta Urban Agglomeration (2016-2030)' put forward sustainable-development vision of conservation of key eco-space and cooperation for air and climate regulation in 2016 [25]. This study takes the YRD region as an example to investigate the land use policy influence on spatiotemporal change of carbon storage in an urbanizing region. The specific objectives of this study are to (1) identify the spatiotemporal dynamics of carbon storage in five periods (1990-1995, 1995-2000, 2000-2005, 2005-2010, 2010-2015); (2) analyze the LULC conversion in five periods and explore the land use policy influences in each period, thus providing a reference for future land management in carbon storage conservation and carbon neutrality in a rapidly urbanizing region.

\section{Material and Methods}

\subsection{Study Area}

The YRD region is located in the eastern coastal region of China (Figure 1). It is in the subtropical monsoon climate region. The wind direction is from southeast to northwest in spring and summer, while it is from northwest to southeast in autumn and winter. There is large spatial disparity in landforms and ecosystems in this region: the north part of the region is mainly covered by plain areas, while the south and west part of the region are mainly mountainous areas. Built-up land and cropland are mainly distributed in the northeast plain region, forest and grassland are mainly distributed in the southwest region. According to the 'Development Plan of Yangtze River Delta Urban Agglomeration' published in 2016, there are three provinces (Jiangsu Province, Zhejiang Province and 
Anhui Province, China) and one central municipality (Shanghai, China). The planned area covers $217,700 \mathrm{~km}^{2}$. In 2014, the GDP of the region reached 1267 trillion yuan, with a total population of 150 million, accounting for $2.2 \%, 18.5 \%$, and $11.0 \%$ of the whole country, respectively [25].

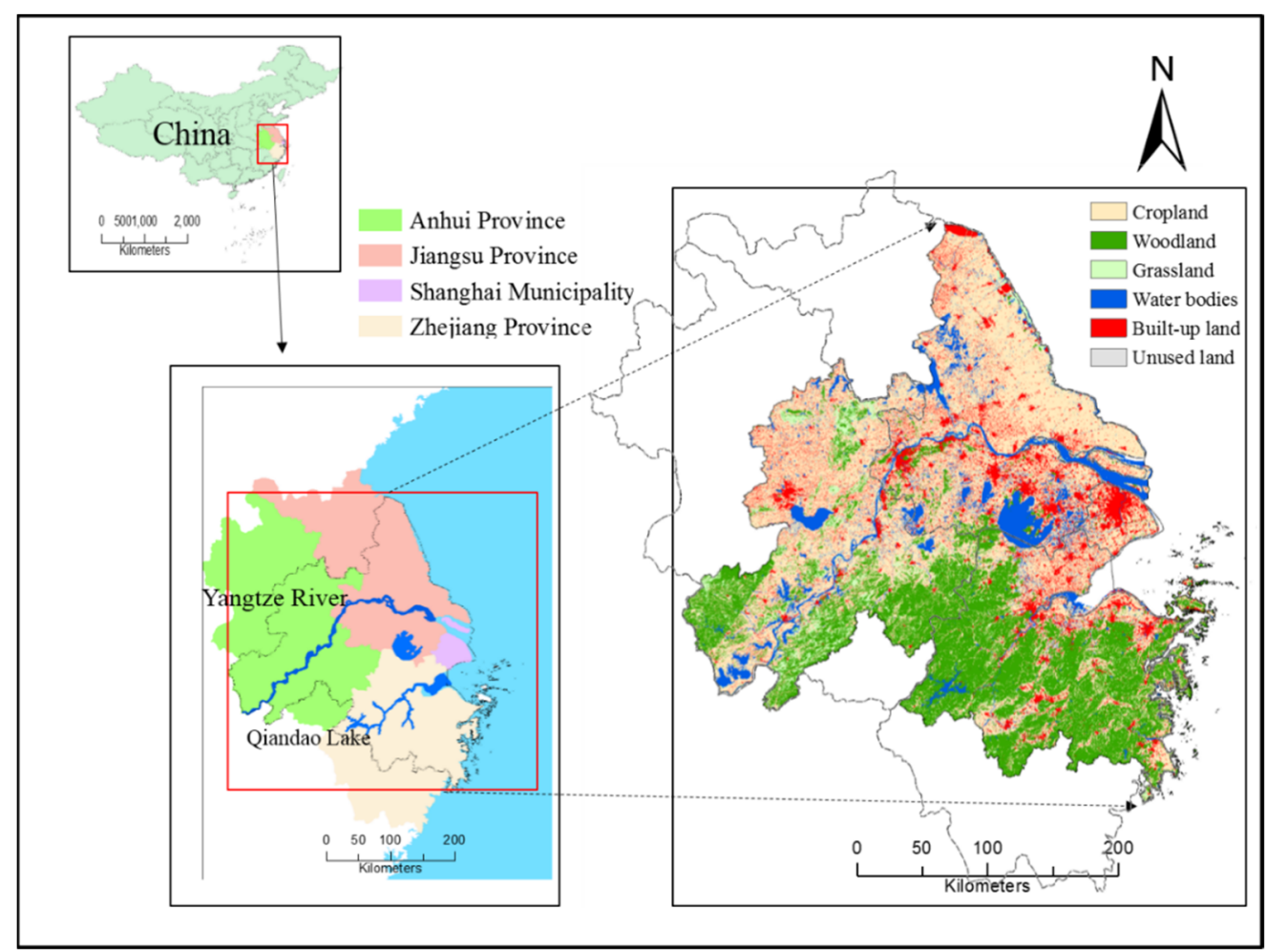

Figure 1. Location and land use/land cover of Yangtze River Delta Region (2015).

\subsection{Land Use and Land Cover}

LULC raster dataset in 1990, 1995, 2000, 2005, 2010, and 2015 at $30 \times 30 \mathrm{~m}$ spatial resolution were from the Chinese Academy of Sciences Geography Science and Resource Institute (http:/ / www.resdc.cn/DataList.aspx: accessed on 6 June 2018). A kappa test was used to verify the classification quality by using historical land use maps and random sampling surveys. The overall accuracy for all images were greater than $75 \%$ for average $86 \%$. The digital grids, which have a resolution of $30 \mathrm{~m}$, were classified into six LULC categories: (1) Woodland: deciduous woodland, evergreen woodland, mixed woodland; (2) Grassland: typical grassland and shrub land; (3) Waterbodies: lakes, rivers, reservoirs, ponds, swamps, and wetlands; (4) Cropland: orchards, dry cropland and irrigated cropland; (5) Built-up land: urban construction land, rural residential land and traffic land; and (6) Unused land: bare exposed land and unutilized land.

\subsection{Carbon Storage and Sequestration}

We applied the Integrated Valuation of Ecosystem Services and Tradeoffs (InVEST) model in this research, which was widely used to estimate carbon storage with regard to LULC types [4,26-30]. The InVEST model maps and quantifies the amount of carbon stored and sequestered (the difference in carbon storage between two years) at $30 \times 30 \mathrm{~m}$ spatial resolution based on the different land uses and carbon densities per unit area of the four major carbon pools $[14,31]$. The carbon density for LULC type $i$ can be expressed as:

$$
\begin{gathered}
C_{i}=C_{i \_ \text {above }}+C_{i \_ \text {below }}+C_{i \_ \text {dead }}+C_{i \_ \text {soil }} \\
C_{\text {tot }}=\sum_{i=1}^{n} C_{i} \times S_{i}
\end{gathered}
$$


where $i$ is a type of LULC; $C_{i}$ is the carbon storage of LULC type $i(\mathrm{Mg} / \mathrm{ha}) ; C_{i \_ \text {above }}$ is the aboveground carbon storage of LULC type $i(\mathrm{Mg} / \mathrm{ha}) ; C_{i_{-} \text {below }}$ is the belowground carbon storage of LULC type $i(\mathrm{Mg} / \mathrm{ha}) ; C_{i_{-} \text {dead }}$ is the dead organic carbon storage $(\mathrm{Mg} / \mathrm{ha})$ of LULC type I; $C_{i_{-} \text {soil }}$ is the carbon storage (Mg/ha) of soil with soil use type I; $C_{t o t}$ is the total carbon storage (Mg) of the ecosystem; $S_{i}$ is the area of LULC type $i$ (ha); and $n$ is the number of LULC types, with the $n$ in this paper being 6 . In this study, we derived carbon storage per unit area of each LULC type (Table 1) from the following references in China [4,32-34].

Table 1. Carbon storage per unit area of each LULC type [30] (Unit: ton/ha).

\begin{tabular}{ccccccc}
\hline LULC & Woodland & Grassland & Surface Waters & Cropland & Built-Up Land & Undeveloped Land \\
\hline above & 26.9 & 17.7 & 8.2 & 15.8 & 1.2 & 11.3 \\
below & 59.2 & 44.2 & 39.5 & 40.3 & 27.6 & 32.4 \\
soil & 122.3 & 49.9 & 40.6 & 54.2 & 43.2 & 53.8 \\
dead & 17.6 & 1 & 0 & 5 & 0 & 0 \\
density & 226 & 112.8 & 88.3 & 115.3 & 72 & 97.5 \\
\hline
\end{tabular}

Note: carbon storage per unit area of each LULC type was according to following studies: woodland [32], grassland [33], surface waters [34], cropland [34], built-up land [30], undeveloped land [4].

The economic value could also be estimated by carbon price (23. $72 \mathrm{RMB} / \mathrm{ton})$ in 2015 of national carbon exchange pilots according to 'Technical specification for accounting gross ecosystem product (GEP) - Terrestrial ecosystems' published by Zhejiang Provinces in September 2020 (http:/ / db33.cnzjqi.com/ewebeditor/uploadfile/20200930 145340879.pdf: accessed on 16 September 2021), and annual average exchange rate as of 2015: 1 USD $\approx 6.23$ RMB (http:/ /www.pbc.gov.cn/rmyh/108976/109428/index.html: accessed on 16 September 2021).

\section{Results}

\subsection{Status Quo of Carbon Storage and Carbon Sink}

There is an obvious uneven distribution of carbon storage in the south and north of the YRD region in 2015 (Figure 2). The spatial distribution of each time period was similar. The entire region was mainly covered by two value-area: the areas with the highest value (20.34 Mg C ha-1) and the areas with value lower than $13.46 \mathrm{Mg} \mathrm{C} \mathrm{ha}^{-1}$, while the distribution of areas with value between $13.46 \mathrm{MgC} \mathrm{ha}^{-1}$ and $20.34 \mathrm{MgC} \mathrm{ha}^{-1}$ was very rare. The areas with the highest value $\left(20.34 \mathrm{Mg} \mathrm{C} \mathrm{ha}^{-1}\right)$ were continuously and densely distributed in mountainous area in the south of the region, in Zhejiang Province, southwest of Jiangsu Province, and south of Anhui Province. In addition, small patches of this value area scattered in the middle and north of the region. On the contrast, the areas with value (6.48-13.46 Mg C ha-1) were densely distributed in plain area in the middle and north of the region (in Shanghai Municipality, Jiangsu Province and east of Anhui Province), and they patchily scattered in the south of the region. The areas with the lowest carbon storage $\left(6.48 \mathrm{Mg} \mathrm{C} \mathrm{ha}{ }^{-1}\right)$ had patchy pattern in the region and relatively clustered in the middle of the region, (in Shanghai Municipality and south of Jiangsu Province near the Yangtze River Estuary and east of Zhejiang Province near Hangzhou Bay).

In 2015, the two main carbon sinks were woodland and cropland in the YRD region, totally accounted by $85.27 \%$ of total carbon storage (Figure 2). Woodland and cropland accounted for $44.37 \%$ and $40.90 \%$ of total carbon storage, respectively. The woodland has the largest contribution of total carbon storage, while the unused land had very few contributions. The total carbon storage in these two types were much higher than the two types: the total carbon storage of woodland is 14.99-times of grassland, 8.95-times of waterbodies, and 7.26-times of built-up land, while the total carbon storage of cropland is 13.82-times of grassland, 8.25-times of waterbodies, 6.69-times of built-up land.

\subsection{Spatiotemporal Dynamics of Carbon Storage and Sequestration}

The total amount of carbon storage presented a trend of increasing first and then decreasing (Figure 3). There was an increase in 1990-1995 in the total carbon storage, and 
then the total carbon storage kept decreasing in 1995-2015. The total amount of carbon storage increased from $2.91 \times 10^{9} \mathrm{Mg}$ in 1990 to $2.95 \times 10^{9} \mathrm{Mg}$ in 1995, and then decreased to $2.90 \times 10^{9} \mathrm{Mg}$ in 2015. Thus, the total economic value of carbon storage increased approximately from 467.42 million dollars in 1990 to 472.99 million dollars in 1995, and then decreased to 465.01 million dollars in 2015. The amount of carbon sequestration largely decreased from $3.47 \times 10^{7} \mathrm{Mg}$ in 1990-1995 to $-1.20 \times 10^{7} \mathrm{Mg}$ in 2000-2015. The change rate of carbon sequestration decreased from $1.19 \%$ in $1990-1995$ to $-0.41 \%$ in $2000-2015$.

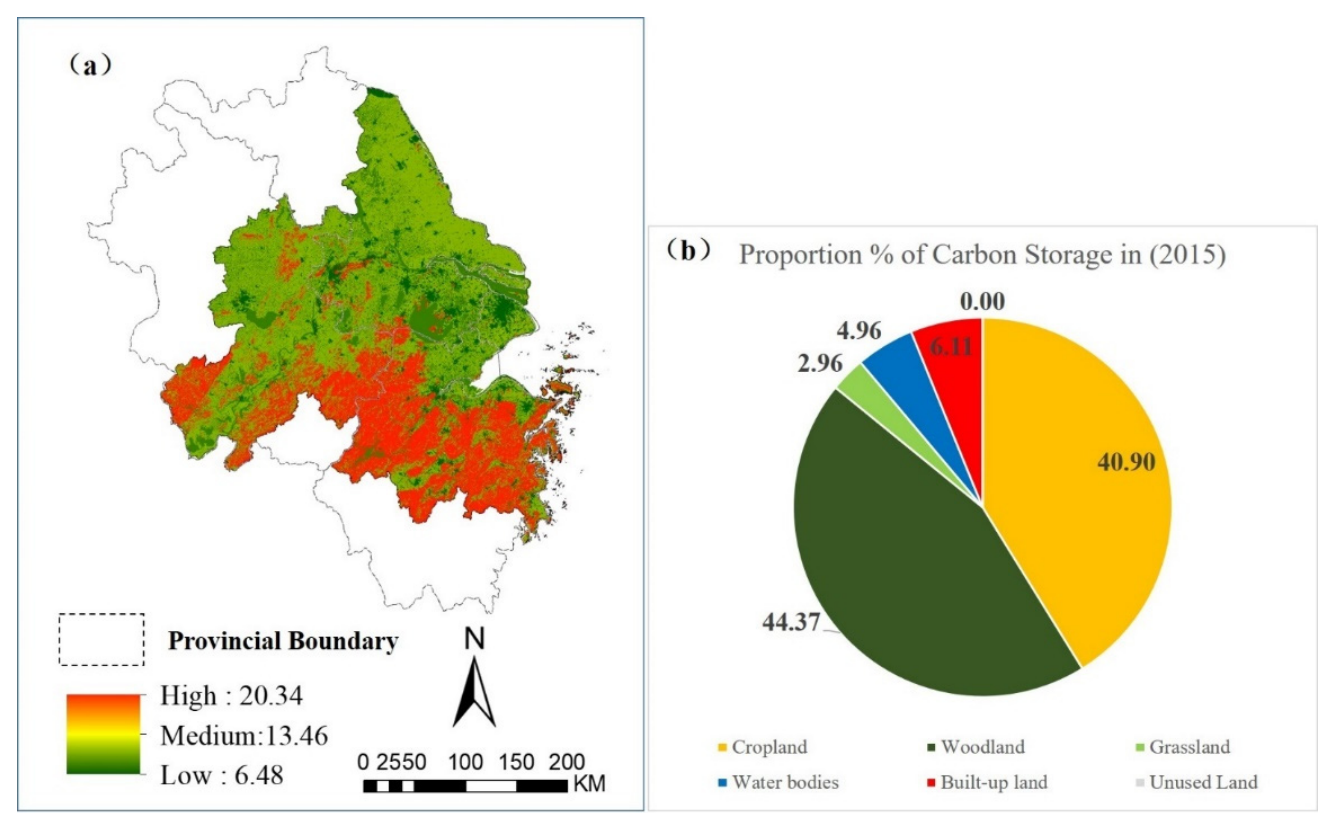

Figure 2. Spatial pattern and proportion \% of carbon storage of Yangtze River Delta Region (2015). (a) Spatial pattern of carbon storage of Yangtze River Delta Region (2015); (b) proportion of carbon storage in LULC of Yangtze River Delta Region (2015).

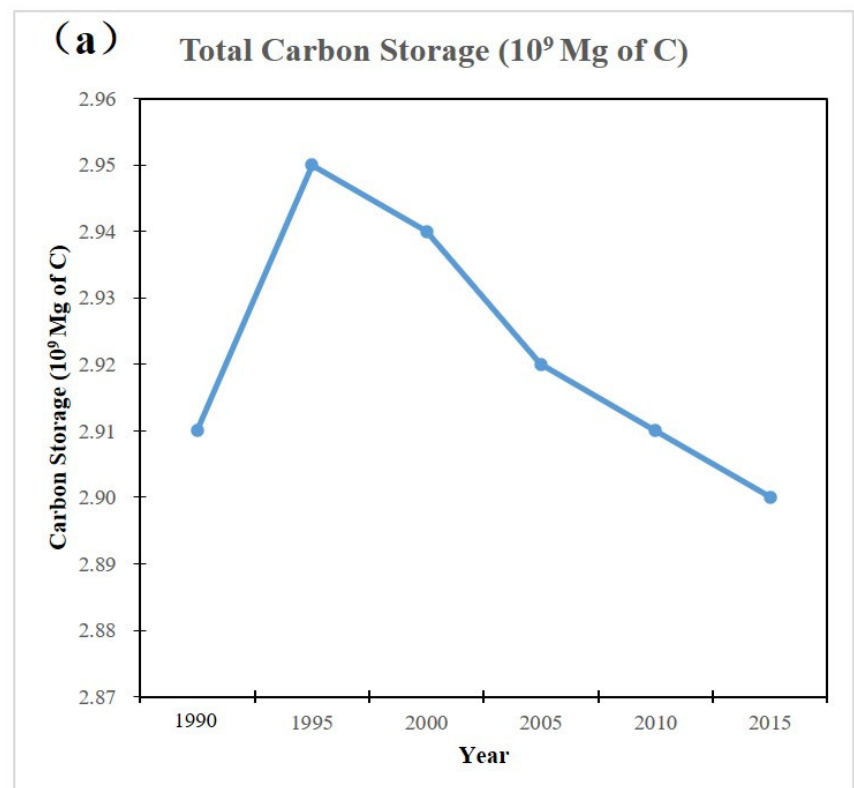

\section{(b) Change of Carbon Storage Proportion in Different LULC: (\%)}

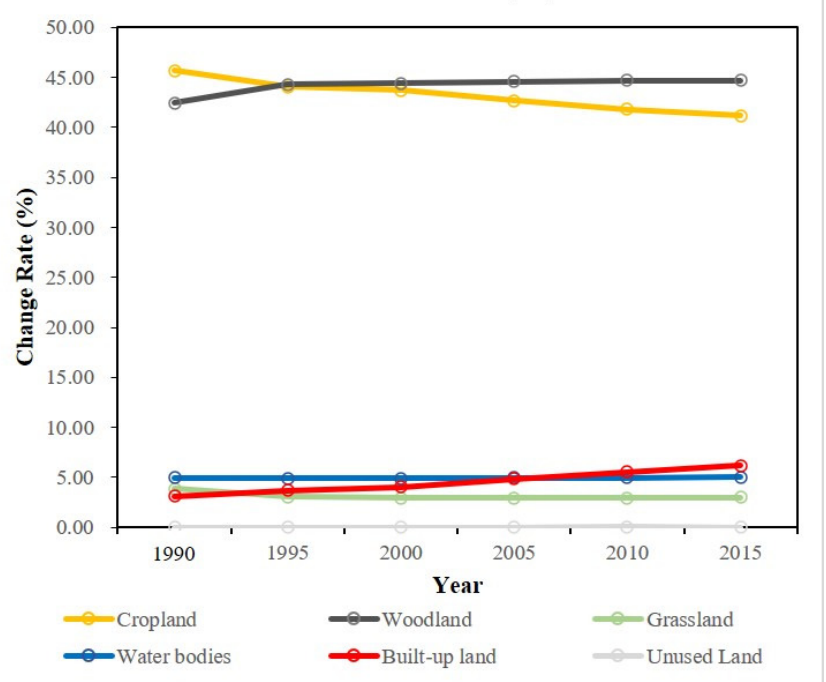

Figure 3. Dynamics and change of proportion of carbon storage of Yangtze River Delta Region (2015). (a) Dynamics of carbon storage of Yangtze River Delta Region (2015); (b) change proportion of carbon storage in LULC of Yangtze River Delta Region (2015). 
There was a decreasing trend of proportion of carbon storage in cropland at average decline rate of $2.25 \%$, while proportion of carbon storage in woodland presented a trend of increased first (5.27\%) in 1990-1995 and decreased later (average -0.26\%) in 1995-2015 (Figure 3). Proportion of carbon storage in grassland presented a trend of decreased first $(-20.71 \%)$ in 1990-1995 and remained relatively stable in 1995-2015. There was a relatively stable trend in proportion of carbon storage in waterbodies, while the proportion in unused land fluctuated in 1990-2015.

In general, the carbon sequestration increased first in the south of the region, while decreased in the middle and north of the region in 1990-1995 (Figure 4). Then, the carbon sequestration remained stable in the south, while the carbon sequestration in the middle of the region kept decreasing in the next four periods, especially in Shanghai Municipality and south of Jiangsu Province near the Yangtze River Estuary and east of Zhejiang Province near Hangzhou Bay.

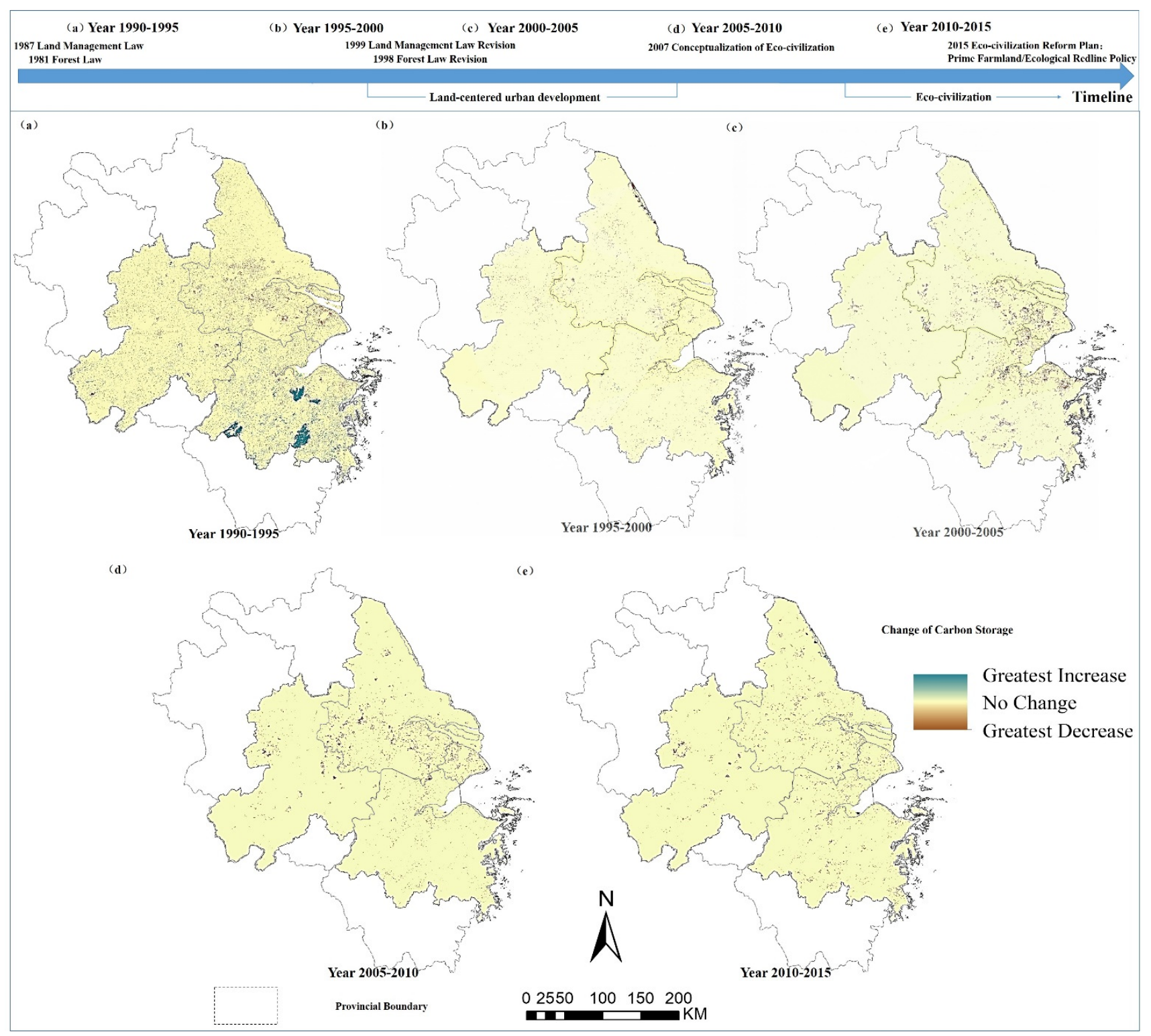

Figure 4. Spatiotemporal change of carbon storage (carbon sequestration) and progress in land use policy in Yangtze River Delta Region (1990-2015). (a) Spatiotemporal change of carbon storage in 1990-1995; (b) Spatiotemporal change of carbon storage in 1995-2000; (c) Spatiotemporal change of carbon storage in 2000-2005; (d) Spatiotemporal change of carbon storage in 2005-2010; (e) Spatiotemporal change of carbon storage in 2010-2015. The timeline above illustrates the progress in land use policy in the Yangtze River Delta Region (1990-2015). 
In 1990-1995, the increased areas of carbon sequestration were concentrated in the south in Zhejiang Province, while the decreased areas were distributed in the middle and west of the region (Figure 4). The increased areas were mainly concentrated in the south of the region in Zhejiang Province. The three largest patches of increased areas were distributed in the south of the region in Zhejiang Province. The decreased areas were distributed in Shanghai Municipality, middle and south of Jiangsu Province and Anhui Province. In 1995-2000, the decreased areas were distributed in Shanghai Municipality, south and east of Jiangsu Province and Anhui Province, while the distribution of increased areas were very rare. In 2000-2005, intensive expansion of decreased areas appeared in the middle of the region, especially in Shanghai Municipality and south of Jiangsu Province near the Yangtze River Estuary and east of Zhejiang Province near Hangzhou Bay. The increased areas were relatively rare and scattered in the entire region. In 2005-2010, the decreased area was concentrated in Jiangsu Province and Shanghai Municipality along with the Yangtze River. In 2010-2015, intensive expansion of decreased areas weakened in central of the region, while the increased areas' distribution was still very rare.

\subsection{Land Use Policy Influences on LULC and Spatiotemporal Pattern of Carbon Storage}

The spatial disparity of carbon storage mainly caused by uneven distribution of natural resources and intensity of LULC, while spatiotemporal dynamics of carbon storage were mainly influenced by LULC change led by land use policies and environmental policies. On one hand, the natural causes of large spatial disparity of carbon storage is mainly related to landform and landscapes distributions of the YRD region: the north and the middle are covered mainly by low-land plain with cropland and built-up land, while the south is mainly covered by mountainous woodland [19]. On the other hand, the spatiotemporal dynamics of carbon storage were mainly influenced by LULC change and land conversion led by land use policies and environmental policies.

The area of built-up land continuously expanded during 1990-2015 at an average of $14.32 \%$, with a considerable net increment $\left(11,956.80 \mathrm{~km}^{2}\right)$, while the area of cropland kept decreasing in 1990-2015 at average 2.25\%. Secondly, the area of forest was increased by $4.18 \%$ during 1990-2015, showing the largest increase during 1990-1995, and then kept decreasing during 1995-2015 at average $0.26 \%$, while the area of grassland had a large decrease first during 1990-1995 at 20.71\%, and then kept decreasing gently during 1995-2015. The above two pairs of dynamics of LULC were strong correlated with land conversion from each other that will be showed in the following Tables 2-6.

Table 2. Land conversion in Yangtze River Delta Region (1990-1995) (area: km²).

\begin{tabular}{cccccccc}
\hline Land Cover. & Cropland & Woodland & Grassland & Water Bodies & Built-Up Land & Unused Land & Total \\
\hline Cropland & $108,718.05$ & 2125.24 & 148.48 & 630.60 & 3617.00 & 2.84 & $115,242.21$ \\
Woodland & 1310.42 & $52,732.62$ & 447.53 & 65.69 & 67.19 & 4.50 & $54,627.96$ \\
Grassland & 240.79 & $2,432.13$ & 7243.86 & 53.38 & 15.00 & 0.45 & 9985.61 \\
Water bodies & 572.39 & 79.03 & 39.03 & $15,537.09$ & 50.20 & 0.25 & $16,277.99$ \\
Built-up land & 1258.34 & 66.23 & 8.73 & 42.18 & $11,276.71$ & 0.26 & $12,652.44$ \\
Unused land & 1.46 & 22.07 & 1.17 & 0.14 & 0.20 & 23.62 & 48.66 \\
Total & $112,101.46$ & $57,457.32$ & 7888.79 & $16,329.08$ & $15,026.30$ & 31.92 & $208,834.87$ \\
\hline
\end{tabular}

Table 3. Land conversion in Yangtze River Delta Region (1995-2000) (area: km²).

\begin{tabular}{cccccccc}
\hline Land Cover & Cropland & Woodland & Grassland & Water Bodies & Built-Up Land & Unused Land & Total \\
\hline Cropland & $110,634.80$ & 10.03 & 1.50 & 316.45 & 1178.13 & 0.98 & $112,141.89$ \\
Woodland & 25.24 & $57,304.73$ & 108.34 & 4.86 & 59.61 & 4.24 & $57,507.03$ \\
Grassland & 95.45 & 115.57 & 7521.78 & 103.45 & 81.44 & 0.03 & 7917.71 \\
Water bodies & 25.34 & 0.55 & 4.58 & $17,550.05$ & 18.83 & 0.00 & $17,599.35$ \\
Built-up land & 24.00 & 0.99 & 0.10 & 2.04 & $15,015.07$ & 0.01 & $15,042.22$ \\
Unused land & 0.04 & 1.37 & 0.00 & 1.24 & 0.11 & 29.48 & 32.23 \\
Total & $110,804.86$ & $57,433.26$ & 7636.30 & $17,978.08$ & $16,353.19$ & 34.73 & $210,240.42$ \\
\hline
\end{tabular}


Table 4. Land conversion in Yangtze River Delta Region (2000-2005) (area: km²).

\begin{tabular}{cccccccc}
\hline Land Cover & Cropland & Woodland & Grassland & Water Bodies & Built-Up Land & Unused Land & Total \\
\hline Cropland & $107,058.77$ & 50.95 & 1.74 & 628.00 & 3064.35 & 158.72 & 0.77 \\
Woodland & 65.98 & $57,147.48$ & 35.84 & 23.27 & 11.74 & $57,4304.57$ \\
Grassland & 44.46 & 25.95 & 7513.26 & 31.58 & 19.44 & 1.53 & 7636.22 \\
Water bodies & 209.69 & 8.24 & 17.31 & $17,645.56$ & 97.00 & 0.00 & $17,977.81$ \\
Built-up land & 36.10 & 2.06 & 0.07 & 10.90 & $16,304.02$ & 0.01 & $16,353.15$ \\
Unused land & 0.00 & 0.19 & 0.00 & 0.00 & 2.68 & 31.85 & 34.73 \\
Total & $107,414.99$ & $57,234.86$ & 7568.23 & $18,339.32$ & $19,646.20$ & 35.90 & $210,239.51$ \\
\hline
\end{tabular}

Table 5. Land conversion in Yangtze River Delta Region (2005-2010) (area: km²).

\begin{tabular}{cccccccc}
\hline Land Cover & Cropland & Woodland & Grassland & Water Bodies & Built-Up Land & Unused Land & Total \\
\hline Cropland & $104,793.56$ & 26.98 & 3.42 & 118.24 & 2472.85 & 0.01 & $107,415.06$ \\
Woodland & 5.98 & $57,094.63$ & 24.69 & 2.69 & 106.68 & 0.38 & $57,235.05$ \\
Grassland & 0.44 & 0.71 & 7537.49 & 16.06 & 13.56 & 0.00 & 7568.26 \\
Water bodies & 10.36 & 0.64 & 1.02 & $18,271.06$ & 56.56 & 0.00 & $18,339.64$ \\
Built-up land & 18.57 & 1.15 & 0.05 & 2.35 & $19,624.25$ & 0.00 & $19,646.37$ \\
Unused land & 0.01 & 0.09 & 0.29 & 0.01 & 0.42 & 35.09 & 35.90 \\
Total & $104,828.92$ & $57,124.20$ & 7566.95 & $18,410.41$ & $22,274.31$ & 35.48 & $210,240.28$ \\
\hline
\end{tabular}

Table 6. Land conversion in Yangtze River Delta Region (2010-2015) (area: km²).

\begin{tabular}{|c|c|c|c|c|c|c|c|}
\hline Land Cover & Cropland & Woodland & Grassland & Water Bodies & Built-Up Land & Unused Land & Total \\
\hline Cropland & $102,566.66$ & 6.02 & 18.63 & 107.20 & 2119.65 & 10.64 & $104,828.80$ \\
\hline Woodland & 7.25 & $56,901.69$ & 14.53 & 4.34 & 194.10 & 1.97 & $57,123.89$ \\
\hline Grassland & 28.06 & 0.52 & 7461.13 & 39.60 & 36.69 & 0.83 & 7566.84 \\
\hline Water bodies & 89.32 & 0.51 & 93.86 & $18,061.99$ & 152.49 & 12.08 & $18,410.24$ \\
\hline Built-up land & 128.49 & 2.82 & 18.09 & 17.72 & $22,105.87$ & 1.35 & $22,274.35$ \\
\hline Unused land & 0.03 & 0.01 & 0.01 & 0.64 & 0.28 & 34.52 & 35.48 \\
\hline Total & $102,819.82$ & $56,911.57$ & 7606.25 & $18,231.49$ & $24,609.08$ & 61.39 & $210,239.59$ \\
\hline
\end{tabular}

In 1990-1995, the large areas of increased areas of carbon storage were mainly contributed to the conversion of grassland to woodland $\left(2432.13 \mathrm{~km}^{2}\right)$ in the south of the region thanks to forest restoration policy. The deceased areas of carbon storage were mainly contributed to the conversation of cropland to built-up land $\left(3617.00 \mathrm{~km}^{2}\right)$ in the middle and north region, which was the largest area of land conversion. In 1995-2000, the decreased areas of carbon storage were mainly contributed to the conversion of cropland to built-up land $\left(1178.13 \mathrm{~km}^{2}\right)$ in the middle and north of the region. In 2000-2005, 2005-2010, and 2010-2015, intensive growth of decreased areas in the middle and south of the region were mainly contributed to the conversion of cropland to built-up land. There was a decreasing trend of conversion of cropland to built-up from 2000 to 2015 (2000-2005: $3064.35 \mathrm{~km}^{2}$, 2005-2010: 2472.85 km², 2010-2015: $2119.65 \mathrm{~km}^{2}$ ).

The implementation of the Forest Law and the Land Management Law both experiences three stages in the YRD region: (1) pre-conservation of forest and cropland, (2) serves land-centered urban development and economic development, and (3) early Eco-civilization stage.

In 1990-1995, the promulgation of 'Forestry Law' in 1981 imposed 'strict controls of annual forest cutting and vigorously promoted afforestation'. As a result, large areas of grassland were restored into woodland. Farmers in the southern mountains no longer lived mainly on tree cutting and farming, while natural vegetation recovered at a quicker pace, and the forest coverage was increased thanks to the reform and opening-up [19,35-38].

In 1995-2010, the YRD region entered a period of rapid development period informed by 'land-centered urban development' and major planned expansion of large cities following the 10th and 11th Five-Year Plan (FYP) focused on economic growth [35], along with noticeably quicker urbanisation, rapid infrastructural construction. Natural ecological 
space, including cropland, was rapidly reduced due to urbanization, disorderly urban sprawl, and construction of infrastructural networks in the eastern plain [19,35-38]. The concept of Eco-civilization was introduced in the 17th CPC National Congress of China at the end of this period.

In 2010-2015, after the conceptualization of national strategy of 'Eco-civilization' in 2012, environmental policies, e.g., Prime Farmland Policy and Ecological Redline Policy. For ensuring the base line of crop protection and crop security, Anhui Province, Jiangsu Province and Zhejiang Province, and Shanghai Municipality delineated prime cropland protection area of $49,211.26 \mathrm{~km}^{2}, 39,220.67 \mathrm{~km}^{2}, 16,675.00 \mathrm{~km}^{2}, 1334.00 \mathrm{~km}^{2}$, respectively, in 2015 according to National Bureau of Statistics (http:/ / www.stats.gov.cn/: accessed on 3 June 2018). For regional ecological redline policy, the provinces and cities in the YRD metropolitan region are embarking on the delineation of ecological red lines and ecological functional zones. For example, Jiangsu Province completed the delineation of provincial ecological red lines, while Nanjing completed the work at the municipal scale. Due to different understandings and definitions of ecological red lines, the delineation results may vary even though the delineated zones are in the same province. Moreover, Zhejiang Province completed functional ecological zoning. For two identical zones, there can be two division versions. Now that the results are not even unified within a province, there may be greater differences when more provinces are involved, and convergence can be more difficult. Therefore, it is imperative to have unified zoning at the regional scale. Therefore, urban expansion and land conversion to built-up land were started to be restrict to a certain extent.

\section{Discussion}

In this study, we detected that the transformation of land use polices in different periods led to spatiotemporal change of carbon storage and sequestration. This result are consistent with Han et al., 2017's findings from 1995-2010 in the two provinces and Shanghai municipality in the YRD region [1]. Our results also detected a totally decreased by $1.49 \times 107 \mathrm{Mg}$ during 1990-2015 with spatial differences in Shanghai Municipality, Jiangsu Province, Zhejiang Province and Anhui Province. This implies that if Shanghai Municipality, Jiangsu Province, Zhejiang Province, and Anhui Province only focused on their own carbon storage conservation planning and were unable to establish cooperation mechanisms, it would have a negative impact on the carbon storage in the entire region. Hence, we suggested that areas with high carbon storage can make more effort on transprovincial boundary conservation planning and management of LULC types of carbon storage, e.g., Shanghai Municipality and Jiangsu Province could establish integrating ecological redline policy with developing cities in mountainous areas in Zhejiang Province and Anhui Province for carbon storage conservation. Moreover, restriction land polices such as prime cropland policy for urban expansion restriction on cropland area will be critical to future conservation of carbon storage.

The period 2010-2015 was the land policy formation period of Eco-civilization strategy. The national objectives of ecological redline policy and prime farmland was put forward officially at the end of the period. During this periods, local land management strategies gradually formed in pilot areas. In the YRD region, pilot areas put forward local pollical objectives and regulations of cropland conservation and ecological zones during this period, e.g., Jiangsu Province initially delineated prime cropland areas, Zhejiang Province formulated forest conservation regulations, and Shanghai Municipality put forward Chongming Ecological Island. These progresses gradually influenced the land use change and carbon storage dynamics during 2010-2015. This was just a beginning that the land use policy of the YRD region started to focus on the quality of ecological land and cropland conservation. High-quality of ecological land and cropland conservation will be the prospective trend for the study area in the near future.

It is vital to reduce carbon emissions in areas that already have low carbon storage, and where carbon sources are important (for instance due to manufacturing/industries). For 
example, the China National Energy Administration issued 'the action plan for clean and efficient utilization of coal (2015-2020)', which comprehensively stimulated the improvement of coal utilization efficiency from the perspective of total coal control, transformation, and utilization efficiency improvement, and supported the development of clean coal technology. The application of clean coal technology in three provinces and one city in the YRD Region is at the leading level in China. Such polices were far from enough for the YRD Region. Green-development policies for quality of urbanization should be taken to improve the capacity of built-up areas of carbon storage, i.e., vegetablization, urban agriculture, and limitation of carbon sources are urgently needed for low-carbon development and carbon neutrality for this highly urbanizing region.

The InVEST model could not fully reflect the actual situation of the YRD region. The carbon storage module assumes that the only change in carbon storage over time is due to changes from one land use type to another $[4,30]$. However, in fact, many areas are recovering from past land use or are experiencing natural succession $[4,30]$. In this study, the carbon pool parameters of six main LULC types used for InVEST model were collected from the previous research for large-scale study in China [4,30,32-34]. To reduce the uncertainties of this method, future results could be optimized by local investigation of carbon pool in more detailed LULC types in our further study at local scale, although we thought they are suitable for regional scale study in China. The accuracy of historical land cover map will lead to uncertainty in spatial pattern identification of land cover change and in detection of land cover conversion. The overall accuracy of the land cover map in this study was around 79.8-86.1\%. It affected the accuracy of land cover change-based results and policy links inference, though the map accuracy met the scientific criteria of the regional scale studies. In addition, an immediate change in carbon storage after LULC change is assumed in this study, though inevitable change in storage to a new steady state can take many decades [39]. In future studies, the spatiotemporal assessment of the relationships between multiple ecosystem services and natural causes and environmental policies in the YRD region also need to be further explored.

\section{Conclusions}

Through InVEST model, the spatial-temporal pattern of carbon storage altered by LULC transformation and its linkage with natural causes and urban expansions were analyzed in YRD Region from 1990-2015: (1) the carbon storage in the YRD was substantially altered by continuous LULC transformation, totally decreased by $1.49 \times 10^{7} \mathrm{Mg}$ during 1990-2015. (2) The total amount of carbon storage increased from $2.91 \times 10^{9} \mathrm{Mg}$ in 1990 to $2.95 \times 10^{9} \mathrm{Mg}$ in 1995, and then decreased to $2.90 \times 10^{9} \mathrm{Mg}$ in 2015. (3) Large areas of grassland converted to woodland in 1990-1995 led by Forest Conservation Law, then clustered areas of cropland were converted to built-up land in 1995-2015 around large cities of YRD region led by Five Year Plans, and finally, the conversion of cropland to built-up land was decreased and scattered in the entire region led by land polices related Eco-civilization.

The study can facilitate to develop regional land use policy for carbon storage conservation and carbon neutrality in a rapidly urbanizing region, e.g., Yangtze River Delta Region. It is expected that high-quality land use polices in Eco-civilization, e.g., Ecological Redline Policy and Prime Farmland Policy, will improve the conversation of carbon sinks in the YRD region. However, it is far from enough to meet the demands of carbon neutrality for such a high urbanizing region. To confront the challenges, current studies should be combined with the evaluation of carbon sources to define a high-quality urbanization in the next stage studies, which will provide a useful tool to assess progress towards the objective of carbon neutrality.

Author Contributions: Conceptualization, W.C.; methodology, W.C.; formal analysis, W.C.; investigation, W.C.; writing — original draft preparation, W.C., and W.P.; writing — review and editing, W.C. and W.P.; supervision, W.P.; project administration, W.C. and W.P.; funding acquisition, W.C. and W.P. All authors have read and agreed to the published version of the manuscript. 
Funding: This research was funded by Shanghai Sailing Program (Grant No. 21YF1419600), National Natural Science Foundation of China (Grant No. 72104232), Big Data-Driven Ecological Security and Natural Resources Early Warning Plan, Key Projects of Philosophy and Social Science Re-search, Chinese Ministry of Education (Grant No. 19JZD023), National Natural Science Foundation of China (Grant No. 31670474), the National Key Research Program of China (Grant No.2016YFC0502701).

Institutional Review Board Statement: Not applicable.

Informed Consent Statement: Not applicable.

Data Availability Statement: Publicly available datasets were analyzed in this study. These data can be found here: Chinese Academy of Sciences Geography Science and Resource Institute (http:/ / www.resdc.cn/DataList.aspx: accessed on 6 June 2018); 'Technical specification for accounting gross ecosystem product (GEP)—Terrestrial ecosystems' published by Zhejiang Provinces in September 2020 (http:/ / db33.cnzjqi.com/ewebeditor/uploadfile/20200930145340879.pdf: accessed on 16 September 2021); National Bureau of Statistics (http:/ / www.stats.gov.cn/: accessed on 3 June 2018).

Acknowledgments: The authors gratefully acknowledge the support of the Shanghai Sailing Program (Grant No. 21YF1419600), National Natural Science Foundation of China (Grant No. 72104232), Big Data-Driven Ecological Security and Natural Resources Early Warning Plan, Key Projects of Philosophy and Social Science Research, Chinese Ministry of Education (Grant No. 19JZD023), National Natural Science Foundation of China (Grant No. 31670474), the National Key Research Program of China (Grant No. 2016YFC0502701).

Conflicts of Interest: The authors declare no conflict of interest.

\section{References}

1. Han, J.; Meng, X.; Zhou, X.; Yi, B.; Liu, M.; Xiang, W.-N. A long-term analysis of urbanization process, landscape change, and carbon sources and sinks: A case study in China's Yangtze River Delta region. J. Clean. Prod. 2017, 141, 1040-1050. [CrossRef]

2. Xu, X.; Tan, Y.; Chen, S.; Yang, G. Changing patterns and determinants of natural capital in the Yangtze River Delta of China 2000-2010. Sci. Total Environ. 2014, 466, 326-337.

3. Li, C.; Zhao, J.; Nguyen Xuan, T.; Xi, Y. Assessment of the Effects of Urban Expansion on Terrestrial Carbon Storage: A Case Study in Xuzhou City, China. Sustainability 2018, 10, 647. [CrossRef]

4. He, C.; Zhang, D.; Huang, Q.; Zhao, Y. Assessing the potential impacts of urban expansion on regional carbon storage by linking the LUSD-urban and InVEST models. Environ. Model. Softw. 2016, 75, 44-58. [CrossRef]

5. Nelson, E.; Sander, H.; Hawthorne, P.; Conte, M.; Ennaanay, D.; Wolny, S.; Manson, S.; Polasky, S. Projecting Global Land-Use Change and Its Effect on Ecosystem Service Provision and Biodiversity with Simple Models. PLoS ONE 2010, 5, e14327. [CrossRef] [PubMed]

6. Xu, Z.; Fan, W.; Wei, H.; Zhang, P.; Ren, J.; Gao, Z.; Ulgiati, S.; Kong, W.; Dong, X. Evaluation and simulation of the impact of land use change on ecosystem services based on a carbon flow model: A case study of the Manas River Basin of Xinjiang, China. Sci. Total Environ. 2019, 652, 117-133. [CrossRef] [PubMed]

7. Deng, X.; Li, Z.; Gibson, J. A review on trade-off analysis of ecosystem services for sustainable land-use management. J. Geogr. Sci. 2016, 26, 953-968. [CrossRef]

8. Zhang, F.; Zhan, J.; Zhang, Q.; Yao, L.; Liu, W. Impacts of land use/cover change on terrestrial carbon stocks in Uganda. Phys. Chem. Earth 2017, 101, 195-203. [CrossRef]

9. Chen, D.; Deng, X.; Jin, G.; Samie, A.; Li, Z. Land-use-change induced dynamics of carbon stocks of the terrestrial ecosystem in Pakistan. Phys. Chem. Earth 2017, 101, 13-20. [CrossRef]

10. Wang, J.; Zhou, W.; Pickett, S.T.A.; Yu, W.; Li, W. A multiscale analysis of urbanization effects on ecosystem services supply in an urban megaregion. Sci. Total Environ. 2019, 662, 824-833. [CrossRef]

11. Zhang, Z.; Peng, J.; Xu, Z.; Wang, X.; Meersmans, J. Ecosystem services supply and demand response to urbanization: A case study of the Pearl River Delta, China. Ecosyst. Serv. 2021, 49, 101274. [CrossRef]

12. Gao, J.; Wang, L. Embedding spatiotemporal changes in carbon storage into urban agglomeration ecosystem management-A case study of the Yangtze River Delta, China. J. Clean. Prod. 2019, 237, 117764. [CrossRef]

13. Lai, L.; Huang, X.; Yang, H.; Chuai, X.; Zhang, M.; Zhong, T.; Chen, Z.; Chen, Y.; Wang, X.; Thompson, J.R. Carbon emissions from land-use change and management in China between 1990 and 2010. Sci. Adv. 2016, 2, e1601063. [CrossRef]

14. Xiang, H.; Jia, M.; Wang, Z.; Li, L.; Mao, D.; Zhang, D.; Cui, G.; Zhu, W. Impacts of Land Cover Changes on Ecosystem Carbon Stocks Over the Transboundary Tumen River Basin in Northeast Asia. Chin. Geogr. Sci. 2018, 28, 973-985. [CrossRef]

15. Li, Z.; Zhong, J.; Sun, Z.; Yang, W. Spatial Pattern of Carbon Sequestration and Urban Sustainability: Analysis of Land-Use and Carbon Emission in Guang'an, China. Sustainability 2017, 9, 1951. [CrossRef] 
16. Islam, M.; Deb, G.P.; Rahman, M. Forest fragmentation reduced carbon storage in a moist tropical forest in Bangladesh: Implications for policy development. Land Use Policy 2017, 65, 15-25. [CrossRef]

17. Leh, M.D.K.; Matlock, M.D.; Cummings, E.C.; Nalley, L.L. Quantifying and mapping multiple ecosystem services change in West Africa. Agric. Ecosyst. Environ. 2013, 165, 6-18. [CrossRef]

18. Polasky, S.; Nelson, E.; Pennington, D.; Johnson, K.A. The Impact of Land-Use Change on Ecosystem Services, Biodiversity and Returns to Landowners: A Case Study in the State of Minnesota. Environ. Resour. Econ. 2011, 48, 219-242. [CrossRef]

19. Cai, W.; Gibbs, D.; Zhang, L.; Ferrier, G.; Cai, Y. Identifying hotspots and management of critical ecosystem services in rapidly urbanizing Yangtze River Delta Region, China. J. Environ. Manag. 2017, 191, 258-267. [CrossRef]

20. Haas, J.; Ban, Y. Urban growth and environmental impacts in Jing-Jin-Ji, the Yangtze, River Delta and the Pearl River Delta. Int. J. Appl. Earth Obs. Geoinf. 2014, 30, 42-55. [CrossRef]

21. Dong, X.; You, M.; Wang, Q. Demarcating method of prime farmland based on land evaluation. Trans. Chin. Soc. Agric. Eng. 2011, 27, 336-339.

22. Liu, Y.; Fang, F.; Li, Y. Key issues of land use in China and implications for policy making. Land Use Policy 2014, 40, 6-12. [CrossRef]

23. Qian, F.; Wang, Q.; Bian, Z.; Dong, X. Discussion about the permanent basic farmland planning and protection. Chin. J. Agric. Resour. Reg. Plan. 2013, 34, 22-27.

24. Bai, Y.; Wong, C.P.; Jiang, B.; Hughes, A.C.; Wang, M.; Wang, Q. Developing China's Ecological Redline Policy using ecosystem services assessments for land use planning. Nat. Commun. 2018, 9, 3034.

25. DPYRDUA. Development Plan of Yangtze River Delta Urban Agglomeration (2016-2030). China's State Council and the National Development and Reform Commission (NDRC). 2016. Available online: https://Wenk.Baidu.Com/View/539ab63a4afe04a1b171 dea8.Html (accessed on 6 June 2019).

26. Hamel, P.; Chaplin-Kramer, R.; Sim, S.; Mueller, C. A new approach to modeling the sediment retention service (InVEST 3.0): Case study of the Cape Fear catchment, North Carolina, USA. Sci. Total Environ. 2015, 524, 166-177. [CrossRef]

27. Liang, Y.; Liu, L.; Huang, J. Integrating the SD-CLUE-S and InVEST models into assessment of oasis carbon storage in northwestern China. PLoS ONE 2017, 12, e0172494. [CrossRef]

28. Jiang, W.; Deng, Y.; Tang, Z.; Lei, X.; Chen, Z. Modelling the potential impacts of urban ecosystem changes on carbon storage under different scenarios by linking the CLUE-S and the InVEST models. Ecol. Model. 2017, 345, 30-40. [CrossRef]

29. Rashidi, K.; Stadelmann, M.; Patt, A. Valuing co-benefits to make low-carbon investments in cities bankable: The case of waste and transportation projects. Sustain. Cities Soc. 2017, 34, 69-78. [CrossRef]

30. Sun, X.; Lu, Z.; Li, F.; Crittenden, J.C. Analyzing spatio-temporal changes and trade-offs to support the supply of multiple ecosystem services in Beijing, China. Ecol. Indic. 2018, 94, 117-129. [CrossRef]

31. Zhang, D.; Huang, Q.; He, C.; Wu, J. Impacts of urban expansion on ecosystem services in the Beijing-Tianjin-Hebei urban agglomeration, China: A scenario analysis based on the Shared Socioeconomic Pathways. Resour. Conserv. Recycl. 2017, 125, 115-130. [CrossRef]

32. Guo, Z.; Hu, H.; Li, P.; Li, N.; Fang, J. Spatio-temporal changes in biomass carbon sinks in China's forests from 1977 to 2008 . Sci. China-Life Sci. 2013, 56, 661-671. [CrossRef]

33. Fang, J.; Yang, Y.; Ma, W.; Mohammat, A.; Shen, H. Ecosystem carbon stocks and their changes in China's grasslands. Sci. China-Life Sci. 2010, 53, 757-765. [CrossRef]

34. Liu, J.; Wang, C.; Chen, J.; Liu, M.; Zhuang, D. Storages of Soil Organic Carbon and Nitrogen and Land Use Changes in China: 1990-2000. Acta Geogr. Sin. 2004, 59, 483-496.

35. Wang, L.; Wong, C.; Duan, X. Urban growth and spatial restructuring patterns: The case of Yangtze River Delta Region, China. Environ. Plan. B Plan. Des. 2016, 43, 515-539. [CrossRef]

36. Yu, W.; Zhou, W. Spatial pattern of urban change in two Chinese megaregions: Contrasting responses to national policy and economic mode. Sci. Total Environ. 2018, 634, 1362-1371. [CrossRef] [PubMed]

37. Wang, Z.; Fang, C.; Zhang, X. Spatial expansion and potential of construction land use in the Yangtze River Delta. J. Geogr. Sci. 2015, 25, 851-864. [CrossRef]

38. Tian, G.; Jiang, J.; Yang, Z.; Zhang, Y. The urban growth, size distribution and spatio-temporal dynamic pattern of the Yangtze River Delta megalopolitan region, China. Ecol. Model. 2011, 222, 865-878. [CrossRef]

39. Cai, W.; Zhu, Q.; Chen, M.; Cai, Y. Spatiotemporal Change and the Natural-Human Driving Processes of a Megacity's Coastal Blue Carbon Storage. Int. J. Environ. Res. Public Health 2021, 18, 8879. [CrossRef] [PubMed] 